\title{
昇降圧PWM電力形インバー夕を用いた 太陽光発電システム
}

\begin{tabular}{|c|c|c|c|}
\hline E 員 & 長 尾 & 道 & (大分大) \\
\hline 員 & 堀 & 英 & (大分大) \\
\hline 員 & & 耕 & (熊本工大) \\
\hline
\end{tabular}

Photovoltaic system using Buck-Boost PWM Power Inverter

Michihiko Nagao, Member (Oita University), Hideo Horikawa, Senior member (Oita University)

Koosuke Harada, Member (Kumamoto Institute of Technology)

\begin{abstract}
This paper presents a buck-boost PWM power inverter and its application for residential photovoltaic system. The PWM power inverter is realized by driving a inverter constructed with a high frequency buck-boost chopper in the discontinuous conduction mode (DCM). Photovoltaic system with the power inverter has the following advantages: (1) The power generated by the photovoltaic array can be transfered to the load and the utility line under any array voltage, (2) Isolation between the photovoltaic array and the utility line is performed by a small high frequency reactor operating as energy storage element, (3) There is no need of a reactor to link the utility line, (4) Unity power factor operation is provided, (5) So the system configuration is very simple. The input-output characteristics of the system is analyzed. As the result, the ripple component of the array current and the power flow between the interface and the utility line are derived, and verified experimentally.
\end{abstract}

キーワード：フライバックコンバータ, PWM電力形インバータ, 太陽光発電システム, 太陽電池, 電力系統

\section{1、まえがき}

太陽エネルギーの有効利用が省エネルギーや環境問題の 改善から重要な検討課題となっている。このうち太陽光発 電システム（以下, PVシステムと略記）は個人住宅用小規 模分散システムとしての実用化が強く望まれ，中でも太陽 電池と係統間のインタフェース回路がコスト低減の期待さ れる部分となっている(1)一(3)。このインタフェース回路とし ては, 従来, 電圧形インバータが主に検討され, 電流形イ ンバー夕も最近検討され始めた(4)。これらインバータには それぞれ一長一短があるが，本稿ではこれらと異なる方式， 即方電力形インバータをPVシステムのインタフェース回路 に用いることを提案する。この電力形インバータを用いた PVシステムは以下の特徵を持つ。

(1)太陽電池の発電電圧の大小に関わらず, 任意の電力を 負荷や系統に送出できる,

(2)系統と同相の信号で制御することにより，常に高力率 が得られる,

(3)高周波りンク方式のように2 段方式(5)とすることなく， 小形の磁心で絶粶ができる，

(4)系統との連系用りアクトルを必要としない,

(5)上記のことから，回路構成が極めて簡単となり，コス
トの低減が期待できる。

ここで提案する電力形インバー夕は, 昇降圧形チョッパ を基本にインバー夕を構成し(6)（12)，これをリアクトル電 流不連続モード(DCM)で動作させることにより実現される (8) 〜(12)。昇降圧形インバータをPVシステムに用いることは すでに文献(6)及び(7)で提案されているが，そこではインバ 一夕を通常よく用いられているリアタトル電流連続モード で動作させており，DCMで動作させる電力形インバータと しての観点からは検討されていない。

従って，本論文ではます，昇降压PWM電力形インバー夕 回路を示し，その等価回路や基本微分方程式を導出し，本 回路の基本特性を明らかにする。この場合，入力の直流電 源として太隄電池を考之, 太陽電池出力電流のリプル電流 と太陽電池出力抵抗及び回路パラメータとの関係を定量的 に明確にする。次に，本インバー夕を系統と連系した場合 の電力フロー特性を明らかにし，上記の特長を持つPVシス テムが構成できることを示す。

\section{2. 回路構成}

昇降圧形インバータの回路構成はいくつか考えられる(6) 一(12)が，本稿では巻線数が少なく，サージ電圧が低いなど の特徵を持つブリッジ方式昇降圧PWM電力形インバータ 
(以下, PWM電力形インバータと略記)(10)，(12)を検討対象と する。図1にPWM電力形インバー夕を用いたPVシステム の基本構成図を示す(12)。ここで $P V$ は太陽電池， $e_{a c}$ は系統 電圧， $Z_{L}$ は負荷とし，主スイッチ素子としてIGBTを使用し ている。破線で囲まれた部分がPWM電力形インバータで, 昇降圧チョッパを 2 組ブリッジ形に組み合せ，スイッチ $Q_{1}{ }^{\prime}$ 及び $Q_{2}{ }^{\prime}$ で同期整流を行うことにより交流出力電圧 $v_{0}$ を得る。 なお，絶縁の必要がなければ 2 次巻楾を省き，u端子から 直接出力を取り出せばよい。

図 2 (a)はPWM電力形インバータを駆動するための各部信 号波形, インバータ入力電流 $i_{D}, 2$ 次側リアクトル電流 $i_{L}$ 及び出力電压 $v_{0}$ の波形を示したものである。図に示すよう に，入力信号 $v_{i}$ の正の半周期に主スイッチング素子 $Q_{1}$ のゲ 一ト $G_{1}$ にPWM信号 $v_{G}$ を， $Q_{1}{ }^{\prime}$ のゲート $G_{1}{ }^{\prime}$ に矩形波信号 $v_{G}{ }^{\prime}$ をそれぞれ加え，また負の半周期にスイッチ $Q_{2} ， Q_{2}^{\prime}$ のゲ 一ト $G_{2}, G_{2}{ }^{\prime}$ にPM信号 $v_{G 2}$, 矩形波信号 $v_{G 2}$ をそれぞれ加 え，DCM動作させることにより，PV出力電圧 $e_{S}$ を昇降压し た交流出力電力 $P_{0}$ を得ることができる。図2 (b)は図 $2(\mathrm{a})$ の 波形の一部を拡大し，動作状態を示したものであり，スイ ッチ素子の状態により基本的に3つの動作状態を取る。即 ち，主スイッチ素子 $Q_{1}$ がオンで $Q_{2}$ がオフである期間 $T_{1} k^{k}$ インダタタ Lにエネルギーを蓄積し，負荷 $Z_{L}$ にはコンデンサ $C$ よりエルギーが供給される状態 I , 次に $Q_{1}$ が全てオフ になり，Lの蓄積エネルギーが $Q_{1}{ }^{\prime}$ 通じて負荷側に転送さ れる期間 $T_{2}^{k}$ の状態 II，そして一次側の主スイッチ素子が全 てオフでLの蓄積エネルギーが消失し，負荷にはCからのみ のエネルギーが供給される期間 $T_{3}{ }^{k}$ の状態の 3 つである。 このようにリアクトルXに流れる電流を常に不連続にする DCM動作を繰り返すことで, PWM電力形インバータを得 ることができる。さらに，Xに流れる電流はキャリヤ周期 $T_{c}$ 内で必ず0となるため，Xを小形の磁心で構成することが できる。この場合，Lに流れる電流 $i_{D}$ が不連続となるため, インダクタ $L_{F}$ 及びキャバシタ $C_{F}$ からなるフィルタをPVとイ ンバータ間に設け，PV出力電流 $i_{S}$ を連続にしている。また $C_{F}$ の值は，PVから常時最大電力を得るため, 入力信号 $v_{i}$ の

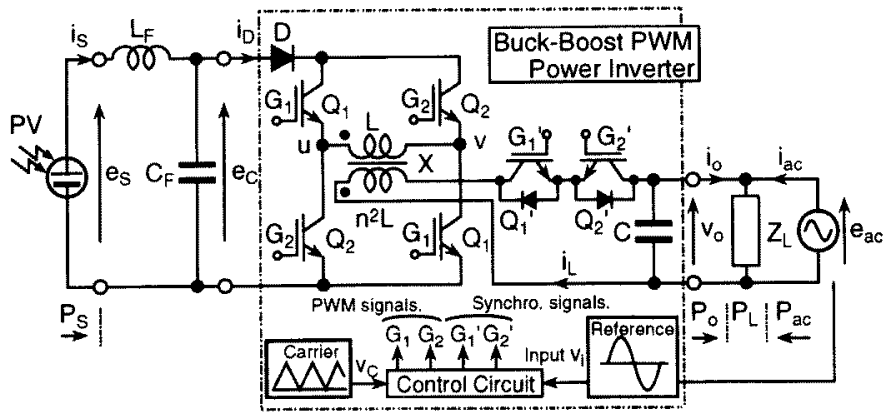

図 1 PWM電力形インバータを用いた 太陽光発電システムの基本構成図

Fig. 1. Basic circuit of photovoltaic system using buck-boost PWM power inverter .
周波数 $f_{j}$ (二系統周波数)成分のリプル分を十分抑制する大き さが必要である。

系統と連系する場合には，人力信号 $v_{i}$ の位相を系統電圧

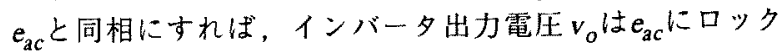
$\left(v_{0}=e_{a d}\right)$ され, 变調率aを変えることによってインバータの出 力電力 $P_{o}$ を制御し， $P V$ から負荷 $Z_{L}$ や系統一任意の電力を転 送することが可能となる。

\section{PWM電力形インバータの基本特性}

$P V$ 出力電流 $i_{S}$ のリプル電流を抑制するため, 通常はPVの 出力端に適当な值のコンデンサを接続してリプルを吸収し ており，定量的な裏付けのもとにコンデンサの值は決定さ れていないようである。このため，まずPWM電力形インバ 一夕の入力側上りみた等価回路を求め, $P V$ 出力電流の低周 波リプルと回路パラメータとの関係を明らかにする。次に 本インバータの出力方程式及び出力電圧を求める。以上の 解析結果を実験により検証する。

解析にあたり以下の仮定を設ける。

(1) 入力信号周波数 $f_{j}$ とキャリヤ周波数 $f_{c}\left(=1 / T_{c}\right)$ との間には， $f_{i} \ll f_{c}$ なる関係がある。

(2)スイッチ素子のスイッチング特性は理想的である。

(3)IGBT及びダイオードは順方向抵抗は 0, 逆方向抵抗は

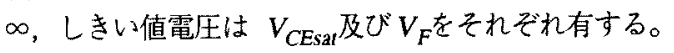

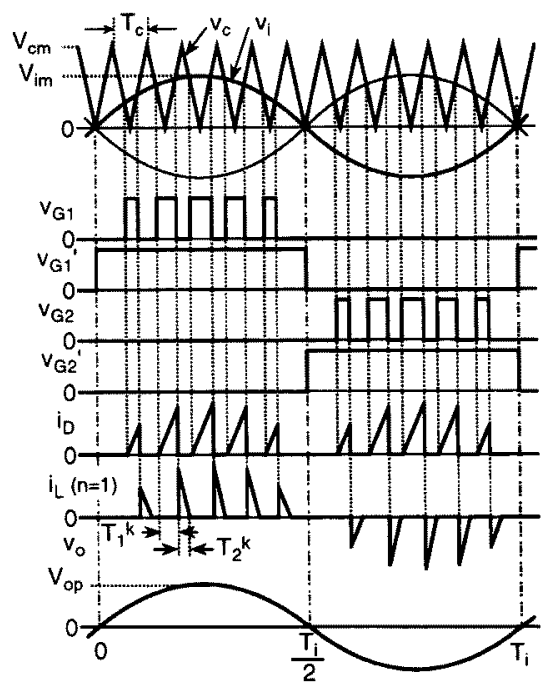

(a) For input signal period $T_{i}$.

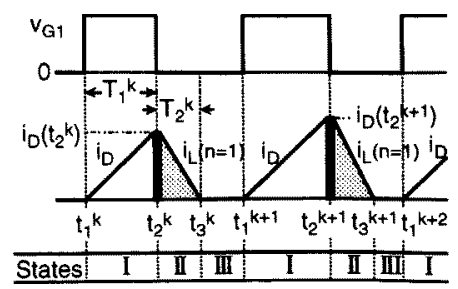

(b) For carrier period $T_{c}$.

図 2 回路各部信号, 電圧, 電流波形

Fig. 2. Waveforms of signals, currents and output voltage . 
(4) 回路素子及び線路の寄生成分は無視する。

(5)インバータ入力電圧 $\mathrm{e}_{C}$ のリプル分は十分小さく, $\mathrm{e}_{C} \fallingdotseq$ $E_{C}$ の直流一定電圧とする

(6) 負荷 $Z_{L}$ は純抵抗 $R_{L}$ とする。

<3.1> 動作状態と微分方程式前述の上うに, PWM 電力形インバー夕は基本的に 3 つ動作状態をとる。系統 $e_{a c}$ と接続していない場合, 入力信号 $v_{i}$ の正の半周期につい てこれら各状態の等価回路を求加ると図ふが得られる。な お図中の $V_{D i}$ 及び $V_{D o}$ は導通時のスイッチ素子のしきい值電 圧からなり，次式で与えられる。

$V_{D i}=2 V_{C E s a t}+V_{F}, V_{D o}=V_{C E s a t}+V_{F}$

图からインバータの入力電压 $e_{C}$, 久力電流 $i_{D}$, 出力電圧 $v_{0}$, 及びリアクトル電流 $i_{L}$ について下の微分方程式を得る。

[Statel]

$$
\left.\begin{array}{l}
\frac{d i_{D}(t)}{d t}=\frac{E_{C}-V_{D i}}{L} \\
\frac{d v_{o}(t)}{d t}=-\frac{v_{o}(t)}{C R_{L}}
\end{array}\right\}
$$

[StateIl]

$$
\left.\begin{array}{l}
\frac{d i_{L}(t)}{d t}=\frac{v_{o}(t)+V_{D o}}{n^{2} L} \\
\frac{d v_{o}(t)}{d t}=\frac{i_{L}(t)}{C}-\frac{v_{o}(t)}{C R_{L}}
\end{array}\right\}
$$

[StateII]

$$
\frac{d v_{o}(t)}{d t}=-\frac{v_{o}(t)}{C R_{L}}
$$

<3・2> システムの入力特性 図 2 の波形图から分か るように，本回路の PWM信号は入力信号 $v_{i}=V_{\text {im }}\left|\sin \left(\omega_{i}\right)\right|$ と 三角波キャリヤ信号 $v_{c}=V_{\mathrm{cm}} \operatorname{tr}\left(\omega_{c}\right)$ とを比較して得られるた め, 期間 $T_{1}{ }^{k}(k=1,2, \ldots)$ は各期間で $v_{j} k よ る$ 変調を受け, 次式 で与えられる。

$$
T_{1}^{k}=a T_{c}\left|\sin \left(\omega_{i} t_{1}^{k}\right)\right|
$$

また，インバータ入力電流的は(2)式より $E_{C}-V_{D}$ に比例する のこぎり波となる。従って， $i_{D}$ 及びそのピーク值 $i_{D}\left(t_{2}{ }^{k}\right) \equiv$ $I_{D P}{ }^{k}$ は(2),(5)式から次式で与えられる。

$$
\left.\begin{array}{l}
i_{D}(t)=\frac{E_{C}-V_{D i}}{L}\left(t-t_{1}{ }^{k}\right) \quad\left(t_{1}{ }^{k} \leq t \leq t_{2}{ }^{k}\right) \\
I_{D P}{ }^{k}=\frac{a T_{C}}{L}\left(E_{C}-V_{D i}\right) \mid \sin \omega_{i} t_{1}{ }^{k_{1}}
\end{array}\right\}
$$

但し， aは変調率であり， $\quad a V_{\mathrm{im}} / V_{\mathrm{cm}}$ である。

このように $i_{D}$ はパルス幅と振幅が変化し， $\omega_{c} t$ と $\omega_{i}$ との関
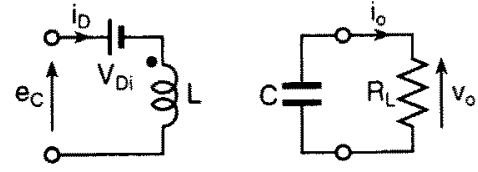

(a) State I

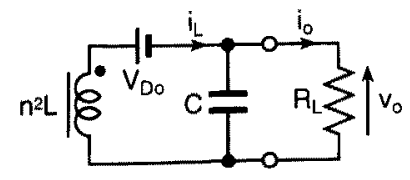

(b) State II

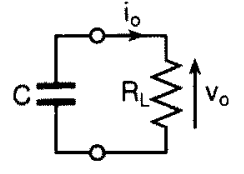

(c) State III
图 3 入力信号の正の半周期における各状態別等価回路

Fig. 3. Equivalent circuits for input signal $v_{i}\left(0<t<T_{i} / 2\right)$.
数になるため、二重フーリエ級数により展開される(13)（14)。 これを複素表示すれば次式を得る。

$$
i_{D}(\theta, \varphi)=\sum_{m=-\infty}^{\infty} \sum_{n=-\infty}^{\infty} K_{m n} e^{j(m \theta+n \varphi)}
$$

但し,

$$
\begin{aligned}
& K_{m n}=\frac{1}{4 \pi^{2}} \int_{0}^{2 \pi} \int_{\theta_{1}^{k}}^{\theta_{2}^{k}} i_{D} e^{-j(m \theta+n \varphi)} d \theta d \varphi \\
& \left.\begin{array}{l}
\theta=\omega_{c} t, \varphi=\omega_{i} t, \theta_{1}^{k}=\omega_{c} t_{1}^{k}, \theta_{2}^{k}=\omega_{c} t_{2}^{k} \\
m, n=0,1,2,3, \ldots
\end{array}\right\}
\end{aligned}
$$

(8)式より $i_{D}$ の直流成分 $K_{00}$, 入力信号周波数 $f_{i}$ の高調波成分 $K_{0 n}$ 及びキャリヤ周波数 $f_{c}$ の高調波成分 $K_{m n}(m \geq 1)$ が求めら れ，(7)式よりi 仗式で表すことができる(付録)。

$$
i_{D}=\frac{E_{C}-V_{D i}}{Z_{C a c}}+i_{c l}+i_{c h}
$$

但し，

$$
\begin{aligned}
& Z_{C a c}=\frac{4 f_{c} L}{a^{2}} \ldots \ldots \ldots \ldots . \\
& i_{c l}=\frac{E_{C}-V_{D i}}{Z_{C a c}} \sin \left(2 \omega_{i} t-\frac{\pi}{2}\right) \\
& i_{c h}=\sum_{\substack{m=-\infty \\
m \neq 0}}^{\infty} \sum_{\substack{m \\
m}}^{\infty} K_{n m} e^{j(m \theta+n \varphi)}
\end{aligned}
$$

(9)式加ら入力儧等価回路はPVO等価回路と共に描けば图 4 で表される。ここで $E_{S O} ， r_{S} ， C_{S}$ はそれぞれ PVの発電電 压，等価出力抵抗，等価容量である。図 4 あるいは(9)（12) 式上りPWM電力形インバータの入力側等価回路は，入力イ ンピーダンス $Z_{C a c} ， f_{i}$ の第 2 高調波成分の低周波りプル電流 源 $i_{c l}$ 及 $f_{c}$ による高周波りブル電流源 $i_{c h}$ で構成されることが 分かる。

(10)式加 $Z_{C x}$ は変調摔 $a^{\circ} 2$ 乗に反比例し， $f_{c}$ 及びイン ダクタしに比例する純抵抗であること，(11)式からPV出力電 流 $i_{S}$ は $f_{i}$ の第 2 高調波成分のみであること，aを大きくすれ ば $Z_{C a c}$ が小さくなり, 低周波りプル電流 $i_{c l}$ が大きくなるこ と等が分かる。

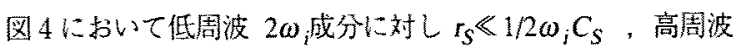
成分に対して1/ $\omega_{c} C_{F} \ll \omega_{c} L_{F}$ 及び仮定(1)を考虑すれば，直流 分，2 20 成分及び高周波成分に対する定常状態の等価回路は 図 5(a),(b)，(c)でそれぞれ表される。キャリヤ信号vにより発 生するリプル電流 $i_{c h}$ はの周波数が十分高く $C_{F}$ でバイパス されるため， $C_{F}$ の電圧 $e_{c h}$ は $e_{c h} \fallingdotseq 0$ となりPVへの影響ははは 無視できる。このためここでは直流分と低埖波成分につい て解析を行う。特に後者はPV留力電流的にリプルを生しさ せ，常時 $P V$ から最大電力を得る妨げの原因となる。徉って， このりプル分を回路パラメータとの関係で定量的に明磼に する。

なお， $E_{S O} ， r_{S}$ は本来日射量や温度等によって变動する非 楾形素子である(15)が，通常これら条件变化は䒺統周波数 $f_{i}$ に比べ緩慢であり，またPVを最大電力近傍で動作させるこ とから，これらパラメー夕は一定として以下の解析を行う。

図 5 (a)から，PV出力端での電圧 $e_{S}$ の平均值を $E_{S}$ とすれば $E_{C}=E_{S}$ でり， $P V$ 平均出力電流 $I_{S}$ は次式で与えられる。 


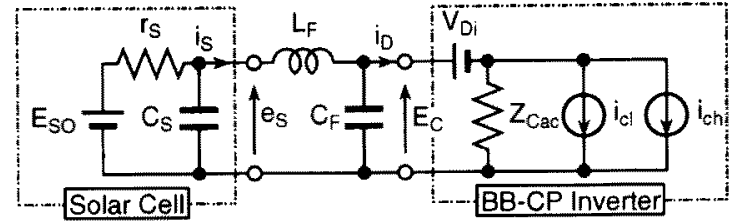

図 4 システムの人力側等価回路

Fig. 4. Equivalent circuit for Fig. 1.
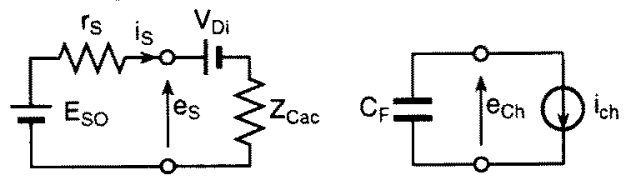

(a) DC component

(c) High frequency component.

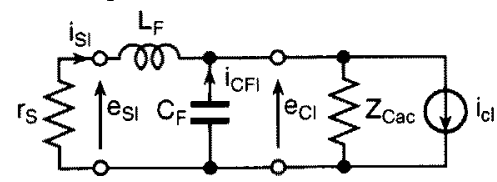

(b) Low frequency $2 \omega_{i}$ component.

図 5 各成分に対する入力側等価回路

Fig. 5. Equivalent circuits for each component.

$$
\left.\begin{array}{l}
I_{S}=I_{D}=\frac{E_{S}-V_{D i}}{Z_{C a c}}=\frac{a^{2}}{4 f_{c} L}\left(E_{S}-V_{D i}\right) \\
E_{S}=E_{S O}-r_{S} I_{S}
\end{array}\right\}
$$

また図 5 (b)から電流源 $i_{c l}$ によるリブル電压 $e_{c l}, e_{s l}$ 及びり プル電流 $i_{S I}, i_{C F}$ はフェーザ表示すれば次式で与えられる。

$$
\left.\begin{array}{l}
e_{c l}^{\stackrel{\text { ph }}{=}} E_{c l}=Z I_{c l} e^{j \pi}=\frac{Z I_{S}}{\sqrt{2}} e^{j \frac{\pi}{2}} \\
e_{S l} \stackrel{\text { ph }}{=} E_{S l}=\frac{r_{S}}{r_{S}+j 2 \omega_{i} L_{F}} E_{c l}=\frac{Z r_{S}}{r_{S}+j 2 \omega_{i} L_{F}} \frac{I_{S}}{\sqrt{2}} e^{j \frac{\pi}{2}} \\
i_{S l} \stackrel{\text { ph }}{=} I_{S l}=\frac{E_{c l} e^{j \pi}}{r_{S}+j 2 \omega_{i} L_{F}}=\frac{Z}{r_{S}+j 2 \omega_{i} L_{F}} \frac{I_{S}}{\sqrt{2}} e^{-j \frac{\pi}{2}} \\
i_{C F l} \stackrel{\text { el }}{=} 2 \omega_{i} C_{F} E_{C l} e^{-j \pi / 2}=\sqrt{2} \omega_{i} C_{F} Z I_{S} e^{j \pi}
\end{array}\right\}
$$

但し,

$$
\left.\begin{array}{l}
I_{c t}=\frac{1}{\sqrt{2}} \frac{E_{S}-V_{D i}}{Z_{C a c}} e^{-j \pi / 2} \equiv \frac{I_{S}}{\sqrt{2}} e^{-j \pi / 2} \\
\frac{1}{Z}=\frac{1}{Z_{C a c}}+j 2 \omega_{i} C_{F}+\frac{1}{r_{S}+j 2 \omega_{i} L_{F}}
\end{array}\right\}
$$

(12) (14)式より $P V$ 出力電流 $i_{S}$, リプル幅 $\Delta I_{S p p}$ 及びリプル 率 $\gamma_{i s l}$ は次式で与えられる。

$$
\begin{aligned}
& i_{S}=I_{S}+\sqrt{2}\left|I_{s l}\right| \sin \left(2 \omega_{i} t-\frac{\pi}{2}\right) \\
& \Delta I_{S p p}=2 \sqrt{2}\left|I_{s l}\right|=\left|\frac{2 Z I_{S}}{r_{S}+j 2 \omega_{i} L_{F}}\right| \\
& \gamma_{i s l}=\frac{\Delta I_{S p p}}{I_{S}}=\left|\frac{2 Z}{r_{S}+j 2 \omega_{i} L_{F}}\right|
\end{aligned}
$$

ここで，PVが最大出力電力点 $P_{S o p}$ 動作時には，インバー タの人カインピーダンス $Z_{C x}$ はPVの出力抵抗 $r_{S o p t}$ に等しく，

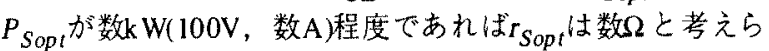
れること，また常時 $P_{\text {Sopt }}$ を得るには $i_{s l}$ を十分小さくする必 要があることなどから， $\Gamma_{S o p r} \gg 2 \omega_{i} L_{F}, 1 / 2 \omega_{i} C_{F}$ となり，
表 1 PWM電力形インバータの回路定数

Table 1. Circuit parameters of PWM power source inverter.

\begin{tabular}{c|c|c|c|c|c|c|c}
\hline $\begin{array}{c}E_{a c} \\
\left(\mathrm{~V}_{\mathrm{RMS}}\right.\end{array}$ & $\begin{array}{c}f_{i} \\
(\mathrm{~Hz})\end{array}$ & $\begin{array}{c}f_{c} \\
(\mathrm{kHz})\end{array}$ & $\begin{array}{c}L \\
(\mu \mathrm{H})\end{array}$ & $\begin{array}{c}C \\
(\mu \mathrm{F})\end{array}$ & $\begin{array}{c}L_{F} \\
(\mu \mathrm{H})\end{array}$ & $\begin{array}{c}V_{C E s a t} \\
(\mathrm{~V})\end{array}$ & $\begin{array}{c}V_{F} \\
(\mathrm{~V})\end{array}$ \\
\hline 100 & 60.0 & 50.0 & 31.0 & 10.0 & 44.0 & 3.0 & 1.0 \\
\hline
\end{tabular}

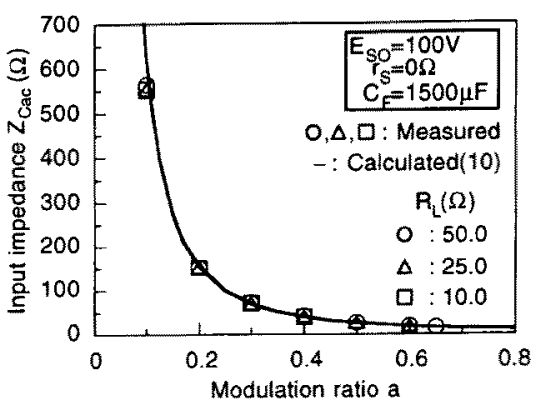

図6 入力インピーダンス $Z_{C a c}$ 特性

Fig. 6. Characteristic of input impedance $Z_{\mathrm{Cac}}$.

(17),(18) 式は次式で近似できる。

$$
\begin{aligned}
& \Delta U_{S p p} \equiv \frac{E_{S}-V_{D i}}{\omega_{i} C_{F} r_{S o p t}{ }^{2}} \\
& \gamma_{i s l} \cong \frac{1}{\omega_{i} C_{F} r_{S o p t}}
\end{aligned}
$$

上式から系統周波数 $f_{i}$ の第 2 高調波成分で変動するリプ 分 $\Delta I_{S p p}$ は， $C_{F}$ 及びPV出力抵抗 $r_{S}$ の2 乗に反比例することが

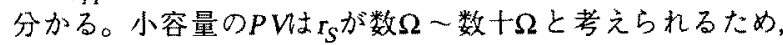
りプル分はある程度の大きさのC $C_{F}$ よって㧕制することが できるが，さらにPVの容量が増加して $r_{S}$ が小さくなると， $C_{F}$ のみによるリプル分の抑制よりも $2 f_{i} に$ 共振する直列 $L C$ フ イルタを $C_{F}$ と並列に接秸することが, 装置の体積・重量の 点から有效と考之られる(16)，(17)。この場合LCフィル夕の 設計に際し，リプル電流 $i_{c l}$ の(11)式は有用なむのとなる。

以上得られた結果を実験により検証する。寒験では，PV の代わりに定電圧電源 $E_{S O}$ と純抵抗 $r_{S}$ を用いている。また， 負荷 $Z_{L}$ 注抵抗 $R_{L}$ であり，系統とは連系していない。なお， 寒験で用いた回路定数は表1に示す。

図6 は変調率aに対するPWM電力形インバータの入力イ ンビーダンス $Z_{C a c}$ 特性を示したものである。図より $Z_{C a c}$ は $R_{L}$ に依存せず，aの2乗に反比例していることが分かる。

図 7 は入力信号 $v_{i}$ LPV出力電流 $i_{S}$ の波形を，同図(a) は実 測波形を，同図(b)は(16)式上り導出した計算波形をそれぞ れ示したものである。これら波形図よりisはv第2 高調波 成分のみのリブル分があることが分かる。

図 8 は $i_{S}$ のリプル $\Delta I_{S p p}$ 特性を示したものである。同図(a) はr に対し $C_{F}$ をパラメータに，同図(b)は $C_{F}$ に対し $r_{S}$ をパラ メー夕に，同図(c)はaに对し，CF辛パラメータとしている。 图 8 にはPV平均出力電流 $I_{S}$ 併記している。図 8 より $\Delta I_{S p p}$ はr $r_{S}, C_{F}$ が大きくなると減少し，aが大きくなると増加してい

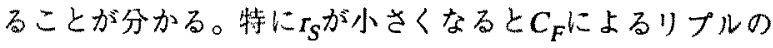
抑制効果は小さくなる。常時, 最大出力電力 $P_{S o p t}$ を得るに 


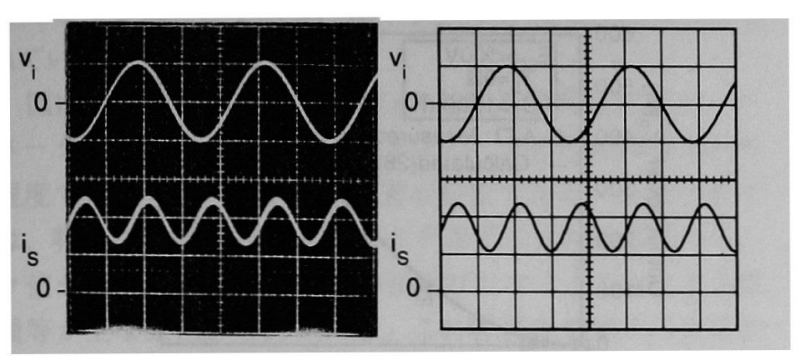

$E_{S O}=100 \mathrm{~V}, r_{S}=2.2 \Omega, L_{F}=44 \mu \mathrm{H}, C_{F}=1500 \mu \mathrm{F}$, $f_{i}=60 \mathrm{~Hz}, f_{c}=50 \mathrm{kHz}, a=0.5, L=31 \mu \mathrm{H}$, $v_{i}: 2 \mathrm{~V} / \mathrm{div}, i_{S}: 2 \mathrm{~A} / \mathrm{div}$, Time $: 5 \mathrm{msec} / \mathrm{div}$

(a) Experimental waveforms.

(b) Calculated waveforms.

図 7 太陽電池出力電流 $i_{S}$ 波形

Fig. 7. Waveforms of solar cell output current $i_{S}$.

は可能な限り $\Delta I_{S p p}$ が小さくなるように $C_{F}$ を設定する必要が あるが, 容量の大きい $P V を$ 設置する場合には, 前述の直列 $L C$ フィルの使用が効果的と考えられる。

$<3 \cdot 3>$ 出力特性 図 2 に示す期間 $T_{1}{ }^{k}$ 及び $T_{2}{ }^{k}$ に対し, (2) 一 (4)式から $i_{D}, v_{o}, i_{L}$ の 2 次近似解を求め, $v_{o}$ に対する差分 方程式を導出すれば, 入力信号 $v_{i}$ の正の半周期に対して次 式を得る(18)。

$$
\frac{v_{o}\left(t_{1}{ }^{k+1}\right)-v_{o}\left(t_{1}{ }^{k}\right)}{d t}=-\frac{1}{C R_{L}} v_{o}\left(t_{1}{ }^{k}\right)+\frac{T_{1}{ }^{k} T_{2}{ }^{k}}{2 n L C T_{C}}\left(E_{C}-V_{D i}\right)
$$

但し,

$$
T_{2}{ }^{k}=n \frac{E_{C}-V_{D i}}{v_{o}\left(t_{1}^{k}\right)+V_{D o}} T_{1}{ }^{k}
$$

仮定(1)及び(5)，(22)式を考慮し，(21)式を微分近似すれば次 式を得る。

$$
\frac{d v_{o}(t)}{d t}=-\frac{1}{C R_{L}} v_{o}(t)+\frac{1}{Z_{C a c} C} \frac{\left\{\sqrt{2}\left(E_{C}-V_{D i}\right) \sin \omega_{i} t\right\}^{2}}{v_{o}(t)+V_{D o}}
$$

ここで簡単のため, $v_{o} \gg V_{D o}$ とすれば, (23)式より出力電圧 $v_{o}$ の定常解 $v_{o s}$ は次式で与えられる。

$$
v_{o s}(t)=V_{o} \sqrt{1-\frac{\cos \left(2 \omega_{i} t-\theta_{0}\right)}{\sqrt{1+\left(\omega_{i} C R_{L}\right)^{2}}}}
$$

但し,

$$
\left.\begin{array}{l}
V_{o}=\sqrt{\frac{R_{L}}{Z_{C a c}}}\left(E_{C}-V_{D i}\right)=a \sqrt{\frac{R_{L}}{4 f_{C} L}}\left(E_{C}-V_{D i}\right) \\
\theta_{0}=\tan ^{-1}\left(\omega_{i} C R_{L}\right)
\end{array}\right\}
$$

入力信号 $v_{i}$ の負の半周期に対しても同様な結果が得られ, 本インバータがスイッチ素子 $Q_{1}{ }^{\prime} ， Q_{2}{ }^{\prime}$ で同期整流を行って 交流出力を得ていることから， $v_{i}$ の全周期にわたって(24)式

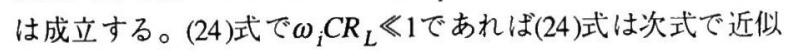
される。

$$
v_{o}(t) \cong V_{o} \sqrt{1-\cos 2 \omega_{i} t}=\sqrt{2} V_{o} \sin \omega_{i} t
$$

このことから出力電圧 $v_{o}$ の波形が $v_{i}$ と同相の正弦波とな るには, キャリヤ周波数 $f_{c}$ を十分高くし, 出力コンデンサ $C$

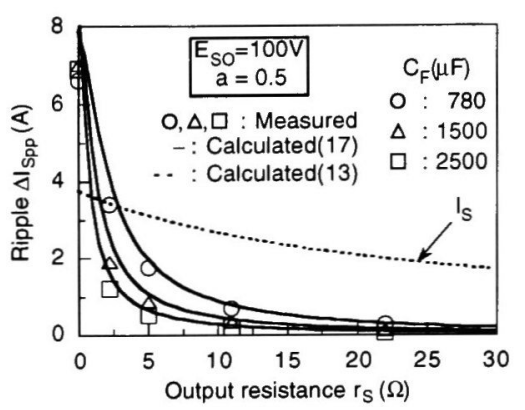

(a) Solar cell output resistance $r_{S}(a=0.5)$.

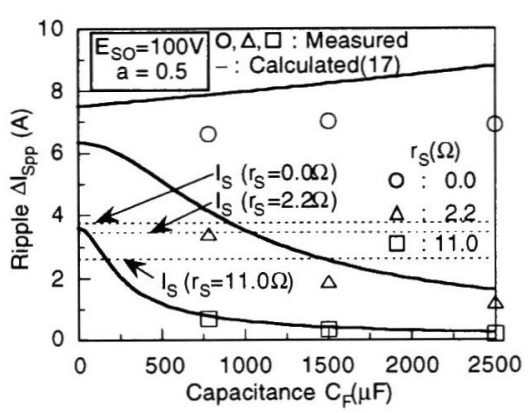

(b) Input filter capacitance $C_{F}(a=0.5)$

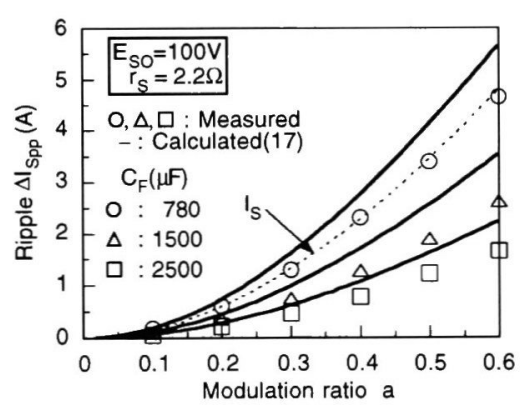

(c) Modulation ratio a $\left(r_{S}=2.2 \Omega\right)$

図 8 リプル $\Delta I_{S p p}$ 特性

Fig. 8. Characteristics of ripple $\Delta I_{s p p}$

と負荷抵抗 $R_{L}$ による時定数 $C R_{L}$ を入力信号角周波数 $\omega_{i}$ に対 し十分小さく設定する必要があることが理解できる。

(25)式で与えられる出力電圧 $V_{o}$ を出力電流 $I_{O}=V_{o} / R_{L}$ で表す と次式が求められる。

$$
V_{o}=\frac{\left(E_{S}-V_{D i}\right)^{2}}{Z_{C a c} I_{o}}=\frac{\left\{a\left(E_{S}-V_{D i}\right)\right\}^{2}}{4 f_{c} L I_{o}}
$$

(27)式から出力電力 $P_{o}$ は,

$$
P_{o}=\frac{\left(E_{S}-V_{D i}\right)^{2}}{Z_{C a c}}=\frac{\left\{a\left(E_{S}-V_{D i}\right)\right\}^{2}}{4 f_{C} L}
$$

で与えられ，負荷抵抗 $R_{L}$ に依存せず定電力特性を示すこと が分かる。また (28)式で与えられる $P_{o}$ は, PWM電力形イン バー夕の入力抵抗が $Z_{C a c}$ であることから, インバータの入 力電力 $P_{S}$ と等しいことが分かる。従って, PWM電力形イン バータを DCM動作させれば, インバータの入力電力 $P_{S}$ を全 て負荷へ転送することが可能となる。 


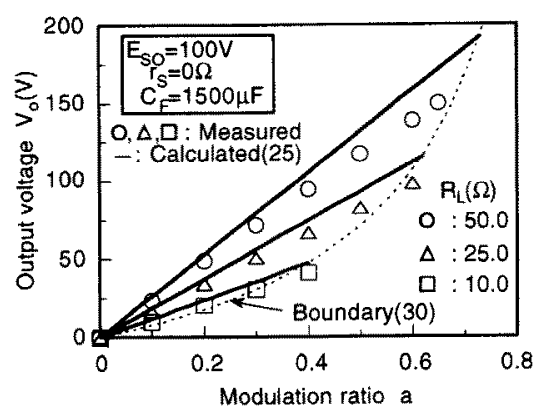

(a) Modulation ratio $a$.

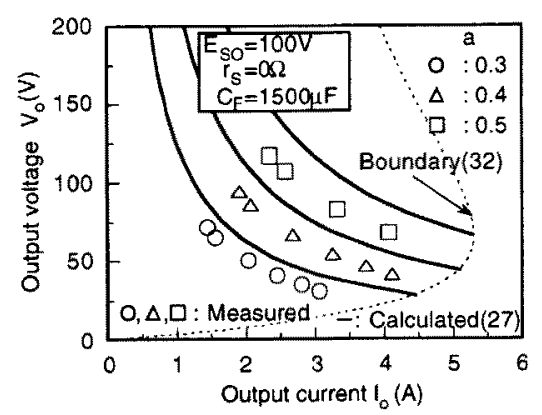

(b) Output current $I_{0}$.

図 9 出力電压 $V_{o}$ 特性

Fig. 9. Characteristics of output voltage $V_{o}$.

本インバータがDCM動作を維持するには，次式を满足す る必要がある。

$$
T_{1}{ }^{k}+T_{2}{ }^{k}<T_{c}
$$

上式と (5), (22), (26)式上り出力電圧 $V_{0}$ 及び変調率にについ て整理すれば次式を得る。

$$
V_{o}>\frac{n\left(E_{S}-V_{D i}\right)}{\sqrt{2}\left(a^{-1}-1\right)}
$$

また(25)式のV索(30)式に代入し，aについて整理すれば次 式を得る。

$$
a<1-n \sqrt{\frac{2 f_{C} L}{R_{L}}}
$$

これから，軽負荷ほど DCM動作領域が大きいことが分かる。

$V_{o}$ に対する出力電流 $I_{0}$ のDCM動作条件は，(27),(30)式よ り次式で与えられる。

$$
I_{o}<\frac{V_{o}\left(E_{S}-V_{D i}\right)^{2}}{2 f_{c} L\left\{\sqrt{2} V_{o}+n\left(E_{S}-V_{D i}\right)\right\}^{2}}
$$

式(32)の右辺を出力電力 $P_{o}=V_{o} I_{o}$ で表わせば次式を得る。

$$
I_{o}<\frac{1}{n\left(E_{C}-V_{D i}\right)}\left\{-\sqrt{2} P_{o}+\sqrt{\frac{\left(E_{C}-V_{D i}\right)^{2}}{2 f_{C} L} P_{o}}\right\}
$$

(32)，(33)式の右辺が最大となる出力電流 $I_{o \max }$ 及びその時の $a=a_{\text {Iomax }}$ は次式で与えられ。

$$
I_{o \max }=\frac{\sqrt{2}\left(E_{S}-V_{D i}\right)}{16 n f_{c} L}, a_{\text {Iomax }}=0.5
$$

従って,この時の出力電压 $V_{\text {olomax }}$ 及び出力電力 $P_{\text {olomax }}$ は(27),

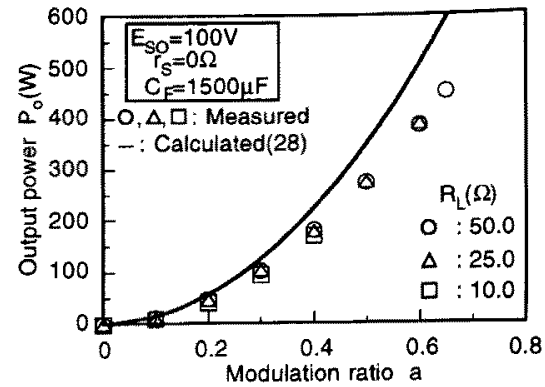

(a) Modulation ratio a

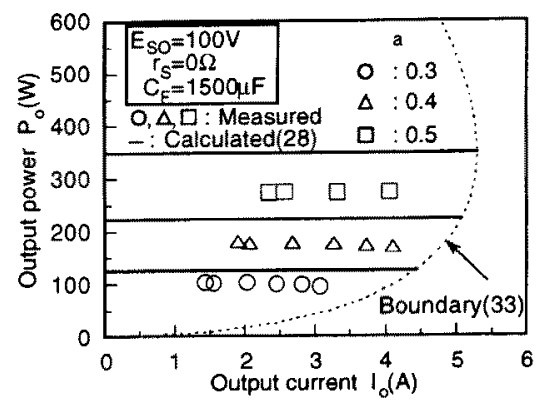

(b) Output current $I_{0}$.

図 10 出力電力 $P_{o}$ 特性

Fig. 10. Characteristics of output power $P_{o}$

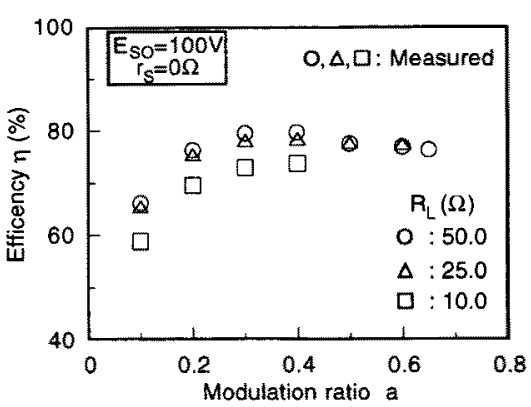

図 11 効率 $\eta$ 特性

Fig. 11. Characteristic of efficiency $\eta$.

(28)，(34)式より次式を得る。

$$
V_{\text {olomax }}=\frac{\sqrt{2} n\left(E_{S}-V_{D i}\right)}{2}, P_{o \text { lomax }}=\frac{\left(E_{S}-V_{D i}\right)^{2}}{16 f_{C} L}
$$

図 9 は出力電圧 $V_{0}$ の特性を，図(a)纥变調率aに対して貨荷 抵抗 $R_{L}$ をパラメー夕として, 四(b)は出力電流 $I_{o}$ に対してaを パラメー夕としてそれぞれ示している。また，破線で示す 特性はDCM動作の境界線を表したもので，破楾左側はDCM 動作を，右側忟リアクトル電流連続モード動作を行う領域 である。これら图からV、は、比例しIに反比例しているこ と，またDCM動作は軽負荷ほど領域が広く， $a_{\text {Iomax }}=0.5$ で最 大負荷電流 $I_{\text {onax }}$ がとれることが分かる。

図10は出力電力P 0 の特性を，眓(a)は変調率、に対して負荷 抵抗 $R_{L}$ をパラメータとして，図(b)は出力電流 $I_{o}$ に対してaを パラメータとしてそれぞれ示している。これら図からP 。 
に対して 2 乗特性を示し， $R_{L}$ に依存せず定電力特性が得ら れていることが分かる。

図11は変調率aに対する効率 $\eta$ の特性を負荷抵抗 $R_{L}$ をパラ メータとして示している。本インバータの効率は最大 $80 \%$ 程度であり，さらに効率の改善が必要である。効率の低下 は, 特にDCM動作のためスイッチ素子に流れる電流のピー ク值が高いため生じるスナバ損及びリアクトルXによる鉄 損等が主な原因と考えられる。これら損失や効率の定量的 解析には, 積分近似(19),(20)が有力な解析法と考えられるが, これについては本回路の効率の改善策と共に今後の検討課 題としたい。

\section{4. 系統連系時の特性}

前章で説明したように, PWM電力形インバータは入力電 力を全て負荷に転送する機能があるため系統と連系し, 系 統電圧 $e_{\mathrm{a}}$ と同相の入力信号 $v_{i}$ でPWM電力形インバータを駆 動すれば，その出力電圧 $v_{o}$ は $e_{a c}=\sqrt{2} E_{\mathrm{ac}} \sin \omega_{i} t$ でロックされ， 発電電力 $P_{S}$ を負荷や系統側へスムーズに転送することがで きる。この場合, 本インバータは電流源として機能し, イ ンバータの出力電力 $P_{o}$ は $P_{o}=E_{\mathrm{ac}} I_{o}$ で与えられ, (28)式の電力 $P_{o}$ と等しくなる。この結果, 出力電流の瞬時値 $i_{0}(t)$ は次式 で与えられる。

$$
i_{o}(t)=\frac{\sqrt{2}\left\{a\left(E_{S}-V_{D i}\right\}^{2}\right.}{4 f_{c} L E_{a c}} \sin \omega_{i} t
$$

これから, 系統電圧 $e_{a c}$ と同相の信号 $v_{i}$ で電力形PWMイン バータを制御すれば, $e_{\mathrm{ac}}$ と同相の電流 $i_{o}$ が得られる。即ち, 力率1で負荷や系統に電力転送が可能であることが分かる。

図12 は系統電压 $e_{a c}$, インバー夕出力電流 $i_{o}$ 及び系統電流 $i_{\mathrm{ac}}$ の実測波形を, (a)は抵抗 $25 \Omega$ 負荷, (b)は無負荷状態の

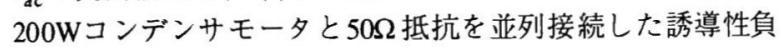
荷についてそれぞれ示したものである。系統電圧 $E_{\mathrm{ac}}$ は $100 \mathrm{~V}$ に設定している。図から負荷の種類に関わらず $e_{a c}$ とほほ同

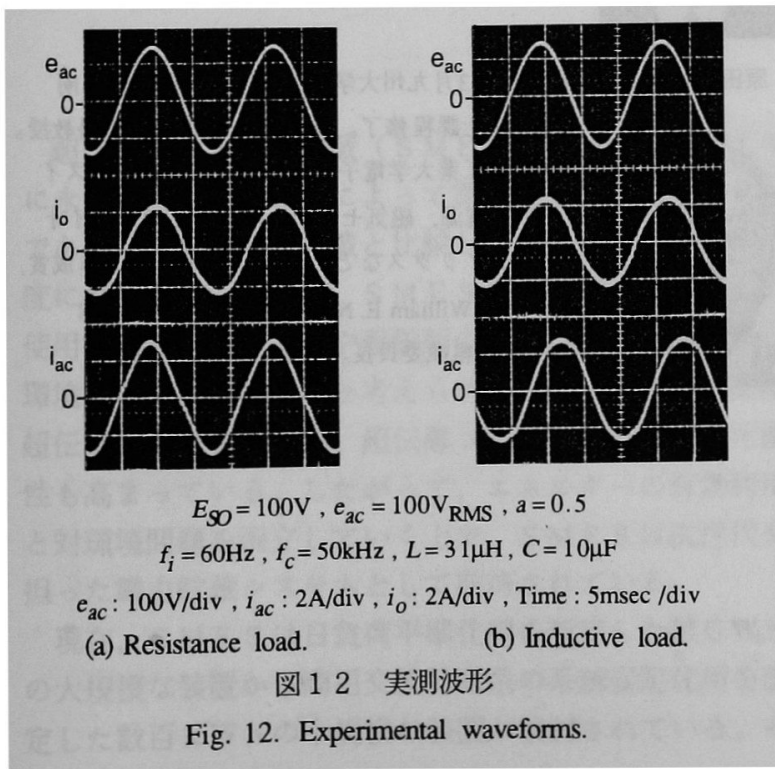

相の電流 $i_{o}$ が流れ, 高力率で $P V$ 発電電力 $P_{S}$ を負荷や系統に 転送していることが分かる。なお， $e_{a c}$ と $i_{0}$ 間のわずかの位 相差は, インバータの出カコンデンサCに流れる無効分が 系統 $\mathrm{e}_{\mathrm{ac}}$ から供給されるため生じている。

図13は電力フロー特性を, 同図(a)は変調率aに対してPV 発電電圧 $E_{S O}$ をパラメータとして, 同図(b)は $E_{S O}$ に対してaを パラメータとしてそれぞれ示している。図から負荷 $R_{L} に$ 出 力電力 $P_{o}$ を供給し, 系統からの電力 $P_{\mathrm{ac}}$ がその分減少してい ること，P $P_{o}$ はaにより制御され， $E_{S O}$ や $r_{S}$ の大小に関わらず $P_{o}$ を負荷に供給できること等がわかる。なお, 計算值の $P_{\mathrm{ac}}$ は $P_{\mathrm{ac}}=P_{L}-P_{o}\left(P_{L}=E_{\mathrm{ac}}^{2} / R_{L}\right)$ 上り求めている。

以上, 3 章から 4 章において計算値と実験値とは良好な 結果を得ている。両者の差異の主な原因は, スイッチング 素子及びィンダクタの抵抗分による損失等を無視したため と考えられる。

\section{5. むすび}

以上, 昇降圧PWM電力形インバータを太陽光発電システ ムに用いた場合の基本的な特性について検討を行なった。 これにより極めて簡単な回路構成で定電力特性が得られ， 太陽電池発電電力の供給がその発電電圧に関わらずスムー ズに，高力率で転送できることが明らかになった。また， 太陽電池の出力電流のリプル分を明確にすることができ, 入力フィルタの設計指針を得ることができた。

本方式を実用化するには, 効率の改善, 系統の短絡, 開 放に対する安全対策等の検討事項が残っているが, 太陽光 発電システムのインタフェース回路として有用な一方式と

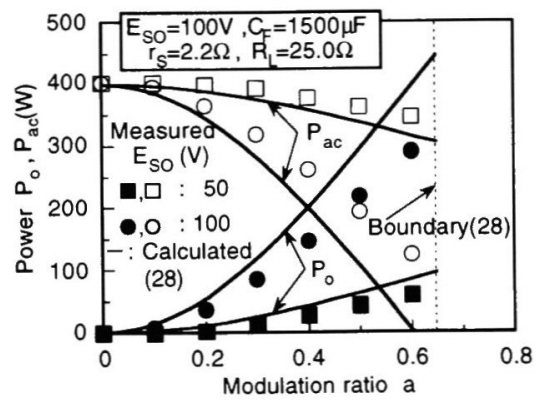

(a) Modulation ratio $a$.

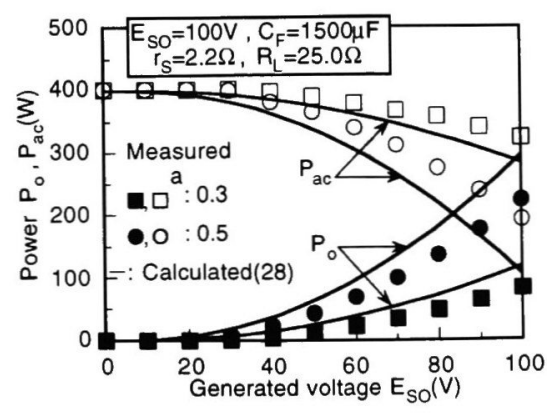

(b) Solar cell voltage $E_{S O}$

図 13 電力フロー特性

Fig. 13. Characteristics of power flow 
考えられる。上記の検討事項は今後の課題としたい。

(平成 5 年 11 月 25 日受付)

\section{文 献}

(1)小林広武:「小型分散太陽光発電の系統連系上の課題と効果」, 平 4電気学会全大, S. $15-2$

(2) 天野隆彦:「太陽光発電技術開発の歩み」, 電学誌, 112,12 , 941 944(平4-12)

(3) 森貞夫・地福順人：「新エネルギー発電及び電力貯蔵におけるパ ワーエレクトロニクス」, 平5電気学会全大, s.8-1

(4)野中作太郎・袈裟丸勝巳 ·山崎清美:「単相PWM インバータによる 太陽光発電連系システム」, 電学論 B，112，5，439４47(平4-5) (5)佐々木敏博:「太陽光発電用インバータの現状と課題」, 電学誌,

$112,12,950 \sim 953$ (平4-12)

(6)M.F.Schlecht:"A Line Interfaced Inverter with Active Control of the Output Current Waveform", PESC 1980 Record, 234 241

(7)松尾博文・黑川不二雄・西良次:「エネルギー蓄積方式正弦波PWM インバータの基本特性について」, 昭59電気関係九州連大, No.737

(8)長尾道彦・井上勝博:「昇降圧形PWMインバー夕の基本特性」，電 気学会研資, SPC-90-101，51 60 (平3-11)

(9) 長尾道彦 ·堀川英雄・原田耕介:「不連続モード動作定電カコンバ 一夕と太陽光発電システムへの応用」, 平4電気学会産業応用部門 全大, No.133

(10)長尾道彦・長友一則・原田耕介:「ブリッジ方式年降圧形PWM 亿 ンバータと高力率UPSへの応用」, 電気学会研資, SPC-92-41，29 36(平4-10)

(11)長尾道彦・堀川英雄・原田耕介: 「不連続モード動作昇降圧形コ ンバータの定電力特性と太陽光発電システムへの応用について」,

信学技報, PE92-22, 9 16(平4-7)

(12)長尾道彦・堀川英雄・原田耕介:「昇降圧形定電力PWMインバー 夕を用いた太陽光発電システム」, 信学技報, PE92-74,35 41 (平 5-2)

(13) 角修吉・源末光·宮越一雄:「サイリス夕増幅器による波形変換」, 電学誌, $87,8,947,1556($ 昭42-8)

(14)谷口勝則・入江寿一・石崎長光:「サイリスタインバータによる PWM電力增幅器」, 電学論 B , 93, 9, 385 390(昭48-9)

(15) 長尾道彦, Harun-UR-Rashid, 中野忠夫:「太陽電池の回路バラメ 一夕の一推定法」, 昭62電気関係九州連大, No.725

(16)竹下隆晴・松井信行 - 外山浩司:「単相PWM コンバータの直流電 圧脈動の一抑制策」, 電学論 D , 113，9，1106１107(平5-9)

(17)野中作太郎:「単相正弦波PWM電圧形インバー夕」, 電気学会研 資, SPC-93-75, 9 - 21(平5-10)

(18) 長尾道彦・森川竜一・原田耕介: 「不連続モード動作高力率ACDC コンバータの特性解析」，信学論C-IL，J75-C-II，11，686〜 695(平4-11)

(19)長尾道彦・町谷洋一・中野忠夫:「高キャリヤ周波数MOS-FET PWM インバータの動作特性」, 信学論C, J71-C，4,510－519(昭 63-4)

(20)逸見次郎・船渡寛人・池田吉克:「PWMインバータの短絡電流抑 制と損失評価」，電学論 D, $111,9,741 \sim 750$ (平3-9)

\section{付 録}

i ) 直流成分 $K_{00}(m=n=0)$;

(5)，(6)，(8)式より，

$$
\begin{aligned}
K_{00} & =\frac{1}{4 \pi^{2}} \int_{0}^{2 \pi} \int_{0}^{2 \pi a|\sin \varphi|} \frac{E_{C}-V_{D i}}{\omega_{C} L} \theta d \theta d \varphi \\
& =\frac{a^{2}}{4 f_{C} L}\left(E_{C}-V_{D i}\right) \quad \ldots \ldots \ldots \ldots \ldots
\end{aligned}
$$

となり，(9)式の第 1 項を得る。

ii) $f_{i}$ の高調波成分 $K_{0 n}(m=0, n \geqq 1)$;

同様に次式を得る。

$$
K_{0 n}=\frac{1}{4 \pi^{2}} \int_{0}^{2 \pi} \int_{0}^{2 \pi a|\sin \varphi|} \frac{E_{C}-V_{D i}}{\omega_{c} L} \theta e^{-j n \varphi} d \theta d \varphi
$$

この式は $n \geq 3$ では $K_{0 n}=0$ となり, $n=2$ のときのみ，

$$
K_{02}=-\frac{a^{2}}{8 f_{c} L}\left(E_{C}-V_{D i}\right)
$$

を持つ。徙って,

$$
\sum_{n=-\infty}^{\infty} K_{0 n} e^{j n \omega_{i} t}=K_{02} e^{j 2 \omega_{1} t} \equiv i_{c l}
$$

となり，(11)式を得る。

iii) $f_{c}$ の高調波成分 $K_{m n}(m \geqq 1, n \geqq 1)$;

$K_{m n}$ は同様にして求めることができるが，この成分は $L_{F} ， C_{F}$ によ クカットされ，i $i_{S}, e_{C}$ んはほとんど影響を与えない。従って， $K_{m n}$ を 求めることは割合し， $K_{m n}$ による高調波電流源を総括して $i_{c h}$ とする。

長尾 道彦 (正員) 68 年3月中央大学電気工学科卒業。同年長

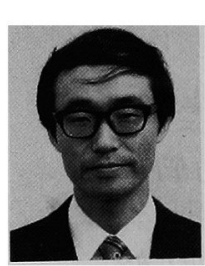
崎大学電気工学科助手。 84 年大分大学電子工学科 助教授。主として応用磁気, スイッチング電源な どの研究に従事。工博

堀川 英雄

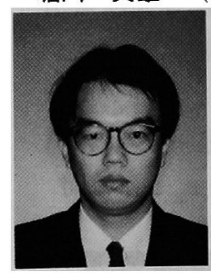

原田 耕介 (正員) 53 年3月九州大学電気工学科卒業。58年同

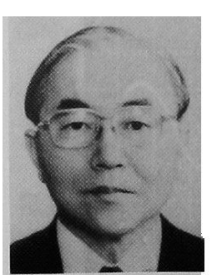
大学院博士課程修了。68 年同大学電子工学科教授。 93年熊本工業大学電子工学科教授。主としてスイ ッチング電源, 磁気センサ, 信頼性工学, バイオ マグネティックスなどの研究に従事。井上春成賞, IEEE 1988 William E. Newell 賞など受賞。1988 IEEE PESC組織委員長。IEEE Fellow。工博。 